\title{
Lysobacter niabensis sp. nov. and Lysobacter niastensis sp. nov., isolated from greenhouse soils in Korea
}

Correspondence Soon-Wo Kwon swkwon@rda.go.kr

\author{
Hang-Yeon Weon, ${ }^{1}$ Byung-Yong Kim, ${ }^{2}$ Min-Kyeong Kim, ${ }^{3}$ \\ Seung-Hee Yoo, ${ }^{2}$ Soon-Wo Kwon, ${ }^{2}$ Seung-Joo Go ${ }^{2}$ \\ and Erko Stackebrandt ${ }^{4}$
}

\begin{abstract}
${ }^{1}$ Applied Microbiology Division, National Institute of Agricultural Science and Technology, Rural Development Administration (RDA), Suwon 441-707, Republic of Korea

${ }^{2}$ Korean Agricultural Culture Collection (KACC), Microbial Genetics Division, National Institute of Agricultural Biotechnology, RDA, Suwon 441-707, Republic of Korea

${ }^{3}$ Environment and Ecology Division, National Institute of Agricultural Science and Technology, RDA, Suwon 441-707, Republic of Korea

${ }^{4}$ Deutsche Sammlung von Mikroorganismen und Zellkulturen $\mathrm{GmbH}$, Mascheroder Weg $1 \mathrm{~b}$, D-38124 Braunschweig, Germany
\end{abstract}

Two bacterial strains, designated $\mathrm{GH} 34-4^{\top}$ and $\mathrm{GH} 41-7^{\top}$, were isolated from greenhouse soil cultivated with cucumber. The bacteria were strictly aerobic, Gram-negative, rod-shaped and oxidase- and catalase-positive. 16S rRNA gene sequence analysis indicated that these strains belong to the genus Lysobacter within the Gammaproteobacteria. Strain GH34-4 ${ }^{\top}$ showed highest sequence similarity to Lysobacter yangpyeongensis $\mathrm{GH} 19-3^{\top}(97.5 \%)$ and Lysobacter koreensis Dae $16^{\top}(96.4 \%)$, and strain $\mathrm{GH} 41-7^{\top}$ showed highest sequence similarity to Lysobacter antibioticus DSM $2044^{\top}$ (97.5\%), Lysobacter enzymogenes DSM $2043^{\top}$ (97.5\%) and Lysobacter gummosus ATCC $29489^{\top}$ (97.4\%). Levels of DNA-DNA relatedness indicated that strains GH34- $4^{\top}$ and $\mathrm{GH} 41-7^{\top}$ represented species clearly different from L. yangpyeongensis, $L$. antibioticus, $L$. enzymogenes and $L$. gummosus. The major cellular fatty acids of strains $\mathrm{GH} 34-4^{\top}$ and $\mathrm{GH} 41-7^{\top}$ were iso- $\mathrm{C}_{16: 0}$, iso- $\mathrm{C}_{15: 0}$ and iso- $\mathrm{C}_{17: 1} \omega 9 \mathrm{c}$, and the major isoprenoid quinone was Q-8. The DNA G $+\mathrm{C}$ contents of $\mathrm{GH} 34-4^{\top}$ and $\mathrm{GH} 41-7^{\top}$ were 62.5 and $66.6 \mathrm{~mol} \%$, respectively. On the basis of the polyphasic taxonomic data presented, it is evident that each of these strains represents a novel species of the genus Lysobacter, for which the names Lysobacter niabensis sp. nov. (type strain GH34-4 $4^{\top}=$ KACC $11587^{\top}=\mathrm{DSM} 18244^{\top}$ ) and $L y$ sobacter niastensis sp. nov. (type strain $\mathrm{GH} 41-7^{\top}=\mathrm{KACC} 11588^{\top}=\mathrm{DSM} 18481^{\top}$ ) are proposed.
The genus Lysobacter was first proposed by Christensen \& Cook (1978) to accommodate non-fruiting, gliding bacteria with a high $\mathrm{G}+\mathrm{C}$ content. Three novel species of the genus, Lysobacter koreensis (Lee et al., 2006), Lysobacter daejeonensis and Lysobacter yangpyeongensis (Weon et al., 2006), isolated from soils, have recently been described. At the time of writing, the genus Lysobacter comprises eight species with validly published names, Lysobacter enzymogenes, L. antibioticus, L. brunescens, L. concretionis, L. daejeonensis, L. gummosus, L. koreensis and L. yangpyeongensis.

The GenBank/EMBL/DDBJ accession numbers for the 16S rRNA gene sequences of strains $\mathrm{GH} 34-4^{\top}$ and $\mathrm{GH} 41-7^{\top}$ are respectively DQ462461 and DQ462462.

A table giving the fatty acid compositions of strains $\mathrm{GH} 34-4^{\top}$ and GH $41-7^{\top}$ is available as supplementary material in IJSEM Online.
In 2005, soil samples were collected from greenhouse soil cultivated with cucumber (Cucumis sativus L.) from the Yongin and Sanju regions, Korea. The samples were serially diluted with $0.85 \% \mathrm{NaCl}(\mathrm{w} / \mathrm{v})$ and suitable 10-fold dilutions were plated onto R2A agar (Difco). The plates were incubated at $28{ }^{\circ} \mathrm{C}$ for 4 days and strains $\mathrm{GH} 34-4^{\mathrm{T}}$ and $\mathrm{GH} 41-7^{\mathrm{T}}$ were subsequently isolated.

For strains $\mathrm{GH} 34-4^{\mathrm{T}}$ and $\mathrm{GH} 41-7^{\mathrm{T}}$, cell morphology was determined by using phase-contrast microscopy of 2-day-old cultures. Gliding motility was observed via oilimmersion phase-contrast microscopy of the edge of colonies in exponential growth phase. The temperature range $\left(5-50{ }^{\circ} \mathrm{C}\right), \mathrm{pH}$ range $(\mathrm{pH} 4-10$ at intervals of $1 \mathrm{pH}$ unit) and requirement for $0,1,2,3,5$ or $7 \% \mathrm{NaCl}$ (w/v) were determined by using R2A medium. Tests for 
Gram staining, catalase, oxidase and hydrolysis of casein, DNA and starch were conducted according to the methods of Smibert \& Krieg (1994). Tests were also made for hydrolysis of CM-cellulose $(0.1 \%$, w/v), chitin from crab shells $(1 \%, \mathrm{w} / \mathrm{v})$ and tyrosine $(0.5 \%, \mathrm{w} / \mathrm{v})$. The commercially available API 20NE and API ID 32 GN (bioMérieux) systems were used to determine biochemical properties, utilization of carbohydrates and enzyme activities according to the manufacturer's instructions. The API ZYM tests were read after $4 \mathrm{~h}$ incubation at $37^{\circ} \mathrm{C}$, and other API tests after $72 \mathrm{~h}$ at $28^{\circ} \mathrm{C}$.

Isoprenoid quinones were analysed by HPLC as described by Groth et al. (1996). DNA-DNA hybridization was carried out as described by Seldin \& Dubnau (1985). Probe labelling was conducted by using the non-radioactive DIG-High prime system (Roche). Reassociation was conducted at $60^{\circ} \mathrm{C}$. Hybridized DNAs were visualized using the DIG luminescent detection kit (Roche). Levels of DNA-DNA relatedness were quantified by using a densitometer (BioRad). For fatty acid methyl ester analysis, cell mass was harvested from R2A agar after cultivation for $48 \mathrm{~h}$ at $28^{\circ} \mathrm{C}$. The fatty acid methyl esters were extracted and prepared according to the standard protocol of the MIDI/Hewlett Packard Microbial Identification System (Sasser, 1990). Determination of DNA G $+\mathrm{C}$ contents was performed according to Mesbah et al. (1989) by using a reversed-phase column (Supelcosil LC-18-S; Supelco).

The 16S rRNA gene was amplified from colonies by PCR using primers fD1 and rP2 (Weisburg et al., 1991) and the entire PCR fragment was directly sequenced (Hiraishi, 1992). The 16S rRNA gene sequences were aligned by using the MEGALIGN program of DNASTAR. A phylogenetic tree was reconstructed with the neighbour-joining method of Saitou \& Nei (1987) on MEGA version 2.1 (Kumar et al., 2001). The stability of relationships was assessed by performing bootstrap analyses of the neighbour-joining data based on 1000 resamplings.

Strains GH34-4 ${ }^{\mathrm{T}}$ and GH41-7 ${ }^{\mathrm{T}}$ were aerobic, Gramnegative, rod-shaped and catalase- and oxidase-positive. They grew well on R2A, trypticase soy agar (Difco) and nutrient agar (Difco), but did not grow on MacConkey agar (Difco). The phenotypic characteristics of strains GH $34-4^{\mathrm{T}}$ and $\mathrm{GH} 41-7^{\mathrm{T}}$ are given in Table 1 and in the species descriptions below. Differential properties among GH34- $4^{\mathrm{T}}, \mathrm{GH} 41-7^{\mathrm{T}}$ and recognized species of the genus Lysobacter are given in Table 1.

Strains GH34-4 ${ }^{\mathrm{T}}$ and GH41-7 ${ }^{\mathrm{T}}$ had ubiquinone-8 (Q-8) as the major isoprenoid quinone, which is a characteristic feature of the genus Lysobacter (Bae et al., 2005). The fatty acid compositions of the novel strains and closely related Lysobacter species are given in Supplementary Table S1 available in IJSEM Online. The major fatty acids detected (percentages of the total cellular fatty acids) from strains $\mathrm{GH} 34-4^{\mathrm{T}}$ and $\mathrm{GH} 41-7^{\mathrm{T}}$ were iso- $\mathrm{C}_{16: 0}$ (23.7 and $23.3 \%$, respectively), iso- $\mathrm{C}_{15: 0}(12.7$ and $21.9 \%)$ and iso- $\mathrm{C}_{17: 1} \omega 9 c$
(10.0 and $10.9 \%$ ). The DNA G +C contents of strains GH34- $4^{\mathrm{T}}$ and $\mathrm{GH} 41-7^{\mathrm{T}}$ were 62.5 and $66.6 \mathrm{~mol} \%$, respectively.

The phylogenetic tree using the almost-complete $16 \mathrm{~S}$ rRNA gene sequence (approximately $1450 \mathrm{bp}$ ) of strains GH34-4 ${ }^{\mathrm{T}}$ and GH41-7 ${ }^{\mathrm{T}}$ showed clearly that the two strains were located within the genus Lysobacter (Fig. 1). Strain GH34-4 $4^{\mathrm{T}}$ was most closely related to $L$. yangpyeongensis $\mathrm{GH} 19-3^{\mathrm{T}}$ (97.5\% 16S rRNA gene sequence similarity). Strain GH41- $7^{\mathrm{T}}$ was grouped with several Lysobacter species, showing highest sequence similarity to L. antibioticus DSM $2044^{\mathrm{T}}(97.5 \%)$, L. enzymogenes DSM $2043^{\mathrm{T}}(97.5 \%)$ and $L$. gummosus ATCC $29489^{\mathrm{T}}(97.4 \%)$. The level of DNA-DNA relatedness between strain GH34-4 ${ }^{\mathrm{T}}$ and $L$. yangpyeongensis GH19- $3^{\mathrm{T}}$ was $25 \%$, and levels between strain GH41-7 ${ }^{\mathrm{T}}$ and the type strains of L. enzymogenes, L. antibioticus and L. gummosus were 42,39 and $32 \%$, respectively.

On the basis of the phenotypic, chemotaxonomic and genetic data presented, it is proposed that strains GH34- ${ }^{\mathrm{T}}$ and GH41-7 $7^{\mathrm{T}}$ should be placed in the genus Lysobacter as the type strains of novel species, with the names Lysobacter niabensis sp. nov. and Lysobacter niastensis sp. nov., respectively.

\section{Description of Lysobacter niabensis sp. nov.}

Lysobacter niabensis (ni.ab.en'sis. N.L. masc. adj. niabensis pertaining to NIAB, National Institute of Agricultural Biotechnology, where taxonomic studies of this taxon were conducted).

Cells are aerobic, Gram-negative rods $(0.5 \times 2.0-5.0 \mu \mathrm{m})$. Growth occurs at $5-37^{\circ} \mathrm{C}$ (optimum $28^{\circ} \mathrm{C}$ ), pH 5-8 (optimum $\mathrm{pH} 6-7$ ) and $0-1 \% \mathrm{NaCl}$. Colonies are yellow and irregular after $48 \mathrm{~h}$ of cultivation at $28^{\circ} \mathrm{C}$ on $\mathrm{R} 2 \mathrm{~A}$ medium. Casein, starch and tyrosine are hydrolysed, but chitin, CM-cellulose, DNA and urea are not. Major cellular fatty acids are iso- $\mathrm{C}_{16: 0}$, iso- $\mathrm{C}_{15: 0}$ and iso- $\mathrm{C}_{17: 1} \omega 9 c$. The detailed cellular fatty acid composition is given in Supplementary Table S1 available in IJSEM Online. The major isoprenoid quinone is Q-8. The DNA G $+\mathrm{C}$ content of the type strain is $62.5 \mathrm{~mol} \%$.

The type strain, GH $34-4^{\mathrm{T}}\left(=\mathrm{KACC} 11587^{\mathrm{T}}=\mathrm{DSM} 18244^{\mathrm{T}}\right)$, was isolated from greenhouse soil in the Republic of Korea.

\section{Description of Lysobacter niastensis sp. nov.}

Lysobacter niastensis (ni.as.ten'sis. N.L. masc. adj. niastensis pertaining to NIAST, National Institute of Agricultural Science and Technology, where taxonomic studies of this taxon were conducted).

Cells are aerobic, Gram-negative rods $(0.5-0.6 \times 2.0-$ $4.0 \mu \mathrm{m}$ ). Growth occurs at $10-40{ }^{\circ} \mathrm{C}$ (optimum $28^{\circ} \mathrm{C}$ ), pH 4-9 (optimum $\mathrm{pH} 6-8$ ) and $0-1 \% \mathrm{NaCl}$. Motile by gliding. Colonies are light beige, convex, round with clear margins after $48 \mathrm{~h}$ of cultivation at $28^{\circ} \mathrm{C}$ on R2A medium. 
Table 1. Differential phenotypic characteristics of strains $\mathrm{GH} 34-4^{\top}$ and $\mathrm{GH} 41-7^{\top}$ and recognized Lysobacter species

Strains: 1, strain GH34-4 $4^{\mathrm{T}} ; 2$, strain GH41-7 ${ }^{\mathrm{T}} ; 3$, L. antibioticus DSM $2044^{\mathrm{T}} ; 4$, L. brunescens DSM 6979 $;$ 5, L. concretionis DSM 16239 ${ }^{\mathrm{T}}$; 6, L. daejeonensis KACC $11406^{\mathrm{T}}$; 7, L. enzymogenes DSM $2043^{\mathrm{T}}$; 8, L. gummosus DSM $6980^{\mathrm{T}}$; 9, L. koreensis KCTC 12204 ${ }^{\mathrm{T}}$; 10, L. yangpyeongensis KACC $11407^{\mathrm{T}}$. Data are taken from Swings \& Christensen (1989), Bae et al. (2005), Lee et al. (2006), Weon et al. (2006) and this study. According to the API 20NE test strips, all strains are positive for gelatin hydrolysis, but negative for indole production, glucose fermentation, arginine dihydrolase and urease. According to the API 20NE and API ID 32GN test strips, all strains are unable to assimilate Larabinose, D-mannitol, potassium gluconate, capric acid, adipic acid, phenylacetic acid, L-rhamnose, D-ribose, inositol, itaconic acid, suberic acid, sodium malonate, lactic acid, L-alanine, potassium 5-ketogluconate, 3-hydroxybenzoic acid, L-fucose, D-sorbitol, propionic acid, potassium 2-ketogluconate or 4-hydroxybenzoic acid. +, Positive; w, weakly positive; -, negative; ND, no data.

\begin{tabular}{|c|c|c|c|c|c|c|c|c|c|c|}
\hline Characteristic & 1 & 2 & 3 & 4 & 5 & 6 & 7 & 8 & 9 & 10 \\
\hline Cell size $(\mu \mathrm{m})$ & $\begin{array}{c}0.5 \times 2.0- \\
5.0\end{array}$ & $\begin{array}{c}0.5-0.6 \times \\
2.0-4.0\end{array}$ & $0.4 \times 6.5$ & $0.3 \times 11.0$ & $\begin{array}{c}0.7 \times 1.0- \\
13.5\end{array}$ & $\begin{array}{c}0.4-0.6 \times \\
3.0-4.0\end{array}$ & $0.5 \times 38.0$ & $0.4 \times 2.0$ & $\begin{array}{c}0.5-0.8 \times \\
1.5-2.0\end{array}$ & $\begin{array}{c}0.4-0.6 \times \\
3.0-4.0\end{array}$ \\
\hline Gliding motility & - & + & + & + & + & - & + & + & $\mathrm{ND}$ & - \\
\hline $\begin{array}{l}\text { Catalase/oxidase } \\
\text { API 20NE:* }\end{array}$ & $+1+$ & $+1+$ & $+1+$ & $+1+$ & $+1+$ & $\mathrm{w} /+$ & $+1+$ & $+/ \mathrm{ND}$ & $+1-$ & $-1+$ \\
\hline Nitrate reduction & - & + & + & - & + & + & - & - & - & - \\
\hline Aesculin hydrolysis & - & + & + & + & - & + & + & + & - & - \\
\hline$\beta$-Galactosidase & - & + & + & - & - & - & + & + & - & - \\
\hline \multicolumn{11}{|l|}{$\begin{array}{l}\text { Assimilation (API 20NE } \\
\text { and API ID 32GN) of: }\end{array}$} \\
\hline D-Glucose & - & $\mathrm{W}$ & + & - & - & + & + & + & - & - \\
\hline D-Mannose & - & - & + & - & - & - & + & + & - & - \\
\hline $\mathrm{N}$-Acetylglucosamine & - & + & + & - & - & - & + & + & - & - \\
\hline D-Maltose & - & + & + & - & - & + & + & + & - & - \\
\hline Malic acid & - & - & + & - & - & - & + & + & - & - \\
\hline Trisodium citrate & - & - & - & - & - & - & + & - & - & - \\
\hline Sucrose & - & - & - & - & - & - & + & + & - & - \\
\hline Sodium acetate & - & - & + & - & + & + & $\mathrm{W}$ & $\mathrm{W}$ & - & - \\
\hline Glycogen & - & - & + & - & $\mathrm{W}$ & + & + & + & - & + \\
\hline L-Serine & - & - & + & - & - & - & + & + & - & - \\
\hline Salicin & - & - & - & - & - & - & + & + & - & - \\
\hline D-Melibiose & - & - & - & - & - & - & + & + & - & - \\
\hline Valeric acid & - & - & + & - & + & + & + & $\mathrm{W}$ & - & - \\
\hline L-Histidine & - & + & + & - & - & - & $\mathrm{W}$ & - & - & - \\
\hline 3-Hydroxybutyric acid & - & - & + & - & + & + & + & + & - & + \\
\hline L-Proline & - & - & + & - & + & - & + & + & - & - \\
\hline $\begin{array}{l}\text { DNA G+C content } \\
(\mathrm{mol} \%)\end{array}$ & 62.5 & 66.6 & 69.2 & 67.7 & 63.8 & 61.7 & 69.0 & 65.7 & 68.9 & 67.3 \\
\hline
\end{tabular}

${ }^{*}$ Data from the present study except those for L. daejeonensis KACC $11406^{\mathrm{T}}$ and L. yangpyeongensis $\mathrm{KACC} 11407^{\mathrm{T}}$.

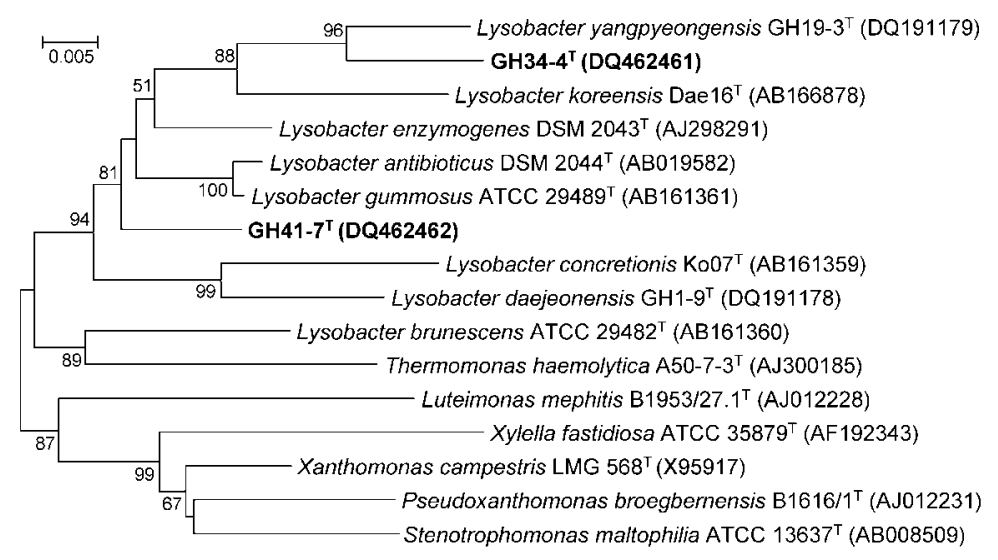

Fig. 1. Phylogenetic tree constructed on the basis of $16 \mathrm{~S}$ rRNA gene sequence analysis of strains $\mathrm{GH} 34-4^{\top}$ and $\mathrm{GH} 41-7^{\top}$ and their relatives. Numbers at nodes indicate levels of bootstrap support (\%) based on a neighbour-joining analysis of 1000 resampled datasets. Only values $>50 \%$ are indicated. Bar, 0.5 substitutions per $100 \mathrm{nt}$. 
Casein, starch and tyrosine are hydrolysed, but chitin, CMcellulose, DNA and urea are not. Major cellular fatty acids are iso- $\mathrm{C}_{16: 0}$, iso- $\mathrm{C}_{15: 0}$ and iso- $\mathrm{C}_{17: 1} \omega 9 c$. The detailed cellular fatty acid composition is given in Supplementary Table S1 available in IJSEM Online. The major isoprenoid quinone is Q-8. The DNA G $+\mathrm{C}$ content of the type strain is $66.6 \mathrm{~mol} \%$.

The type strain, GH41-7 $7^{\mathrm{T}}\left(=\mathrm{KACC} 11588^{\mathrm{T}}=\mathrm{DSM} 18481^{\mathrm{T}}\right.$ ), was isolated from greenhouse soil in the Republic of Korea.

\section{Acknowledgements}

This study was carried out with the support of the programme of international co-operative research work between the Rural Development Administration (RDA), Republic of Korea, and the DSMZ, Germany.

\section{References}

Bae, H.-S., Im, W.-T. \& Lee, S.-T. (2005). Lysobacter concretionis sp. nov., isolated from anaerobic granules in an upflow anaerobic sludge blanket reactor. Int J Syst Evol Microbiol 55, 1155-1161.

Christensen, P. \& Cook, F. D. (1978). Lysobacter, a new genus of nonfruiting, gliding bacteria with a high base ratio. Int $J$ Syst Bacteriol 28, 367-393.

Groth, I., Schumann, P., Weiss, N., Martin, K. \& Rainey, F. A. (1996). Agrococcus jenensis gen. nov., sp. nov., a new genus of actinomycetes with diaminobutyric acid in the cell wall. Int J Syst Bacteriol 46, 234-239.

Hiraishi, A. (1992). Direct automated sequencing of $16 \mathrm{~S}$ rDNA amplified by polymerase chain reaction from bacterial cultures without DNA purification. Lett Appl Microbiol 15, 210-213.
Kumar, S., Tamura, K., Jakobsen, I. B. \& Nei, M. (2001). MEGA2: molecular evolutionary genetics analysis software. Bioinformatics $\mathbf{1 7}$, 1244-1245.

Lee, J. W., Im, W.-T., Kim, M. K. \& Yang, D.-C. (2006). Lysobacter koreensis sp. nov., isolated from a ginseng field. Int J Syst Evol Microbiol 56, 231-235.

Mesbah, M., Premachandran, U. \& Whitman, W. B. (1989). Precise measurement of the $\mathrm{G}+\mathrm{C}$ content of deoxyribonucleic acid by high-performance liquid chromatography. Int J Syst Bacteriol 39, 159-167.

Saitou, N. \& Nei, M. (1987). The neighbor-joining method: a new method for reconstructing phylogenetic trees. Mol Biol Evol 4, 406-425.

Sasser, M. (1990). Identification of bacteria by gas chromatography of cellular fatty acids. MIDI Technical Note 101. Newark, DE: MIDI Inc.

Seldin, L. \& Dubnau, D. (1985). Deoxyribonucleic acid homology among Bacillus polymyxa, Bacillus macerans, Bacillus azotofixans, and other nitrogen-fixing Bacillus strains. Int J Syst Bacteriol 35, 151-154.

Smibert, R. M. \& Krieg, N. R. (1994). Phenotypic characterization. In Methods for General and Molecular Bacteriology, pp. 607-654. Edited by P. Gerhardt, R. G. E. Murray, W. A. Wood \& N. R. Krieg. Washington, DC: American Society for Microbiology.

Swings, J. \& Christensen, P. (1989). Genus I. Lysobacter Christensen and Cook 1978, 372 ${ }^{\mathrm{AL}}$. In Bergey's Manual of Systematic Bacteriology, vol. 3, pp. 2083-2089. Edited by J. T. Staley, M. P. Bryant, N. Pfennig \& J. G. Holt. Baltimore: Williams \& Wilkins.

Weisburg, W. G., Barns, S. M., Pelletier, D. A. \& Lane, D. J. (1991). 16 S ribosomal DNA amplification for phylogenetic study. J Bacteriol 173, 697-703.

Weon, H.-Y., Kim, B.-Y., Baek, Y.-K., Yoo, S.-H., Kwon, S.-W., Stackebrandt, E. \& Go, S.-J. (2006). Two novel species, Lysobacter daejeonensis sp. nov. and Lysobacter yangpyeongensis sp. nov., isolated from Korean greenhouse soils. Int J Syst Evol Microbiol 56, 947-951. 